\title{
Dynamic Models for Seaweed Cultivation Development in The Waters of Luwu and Palopo Regency, South Sulawesi
}

\author{
Waluyo $^{1}$, Yonvitner ${ }^{2}$, Etty Riani² dan Taslim Arifin ${ }^{3}$ \\ Received: $23^{\text {th }}$ December 2019 \\ Accepted: $10^{\text {th }}$ July 2020
}

\begin{abstract}
Waters carrying capacity in the seaweed of Eucheuma cottonii cultures should be a concern for optimum seaweed culture. Carrying capacity can determine by Ecological Footprint (EF) analysis, which in this research use footprint production, and mas balance nitrate analysis. This research on Mei 2015 ( $1^{\text {st }}$ transitional season) and September 2015 ( $2^{\text {nd }}$ transitional season) in Luwu and Palopo, South Sulawesi. Map and land use analyzed with geographic information systems (GIS). The results showed that the Ecological Footprint Production (EFP) in Luwu waters is 67,88 ton/capita/year, or equivalent to $235,823.93$ tons/year. Based on the analysis of the availability of water for seaweed is $38,374.69$ hectares, it can produce seaweed (biocapacity) for $922,928.96$ tons/year and the number of farmers that allows for use the waters is 13,595 capita. The Ecological Footprint Production (EFP) in Palopo waters is 3.08 ton/capita/year, or equivalent to $4,589.99$ tons/year. Water availability analysis is 979.82 hectares can produce seaweed (biocapacity) for 10,115.34 ton/year and the number of farmers that allows for use the waters is 3,276 capita. Based on the four scenario simulation management results of the development seaweed cultivation Eucheuma cottonii in Luwu and Palopo Regency is based on the present waste input, pressing inputs of waste into the waters of $10 \%, 25 \%$ and $50 \%$ yield different waters biocapacity. The results comparison between biocapacity and Ecological Footprint, ecological status for Luwu and Palopo waters are still in sustainable use. Based on those simulation results showed that in the second scenario by pressing the waste input by $10 \%$ from the existing waste input, as well as assuming the availability of water utilizing the entire area of $38,374.69$ hectares continuously (on the years scale of 2008-2030), it will produce the highest biocapacity waters in the amount of $8,257,274.94$ tons/year. So with the management of seaweed in Palopo with the second scenario, assuming the availability of water utilizing the entire area of 979.82 hectares will produce the highest waters biocapacity of $14,306.92$ tons/year.
\end{abstract}

Keywords: dynamic models, seaweed cultivation, ecological footprint, waters carrying capacity, mass balance nitrate

\section{INTRODUCTION}

Seaweed is a leading commodity in South Sulawesi Province, especially in Luwu Regency and Palopo City. Based on the Luwu Regency Marine and Fisheries (DKP) and DKP Palopo City in 2015, the production of dried seaweed species of Eucheuma cottonii from 2010- 2014 in both regions each year continues to increase. Seaweed production in Luwu Regency in 2010 and 2014 amounted to $183,202.80$ tons and $356,385.50$ tons with the percentage increase on average each year by $18.50 \%$ (DKP of Luwu Regency, 2015). While

\footnotetext{
${ }^{1}$ Marine and Fisheries Polytechnic of Karawang

${ }^{2}$ Faculty of Marine and Fisheries, IPB University

${ }^{3}$ Marine Research Center, Ministry of Marine Affairs and Fisheries
} 
the production of seaweed in Palopo 2010 and 2014 amounted to 2,227.04 tons and 3,112.31 tons with an average percentage increase every year amounted to $40.38 \%$ (DKP Palopo, 2015). In addition, the area of water used for seaweed cultivation every year also increases, where the area of water used for seaweed cultivation in Luwu Regency in 2014 was 10,469.24 hectares (DKP Luwu Regency, 2015) and in Palopo City by 313.60 hectares (DKP Palopo City, 2015).

Based on data from DKP Luwu Regency (2015) states that the average productivity of seaweed from 2008-2014 reached 24.05 tons/hectare/year. The productivity of seaweed in Palopo City from 2008-2014 reached 10.32 tons/hectare/year (DKP Kota Palopo, 2015). Aquatic productivity in Luwu Regency is very high due to among them being extensive aquaculture land and more seaweed cultivators than in Palopo City. The average cultivator in Luwu Regency in 2008-2014 reached 3.472 capita, while in Palopo City it only reached 1.503 capita.

The productivity of seaweed in the waters besides being influenced by the area of cultivated land is also strongly influenced by the quality of the waters. While the quality and productivity of the waters are strongly influenced by how much input of organic and inorganic materials originating from the land that enters the waters through the river flow. For example waters in the Regency of Bua, Luwu, a key input load is a domestic waste as well as waste from a plywood factory (plywood) is right near Bua River Estuary. While the waters in Ponrang SubRegency, Luwu Regency, the main burden of water is a domestic waste as well as waste from ponds in the form of fertilizer residues, pesticides, food waste, and other organic materials. As for the waters of Palopo City, the main load of water is waste from activities at the Ponrap Fish Auction Place (TPI) and the Indonesian Fisheries Port (PPI). Thus, the input characteristics of runoff greatly affect the quality and productivity of the waters, which in turn will affect the growth of seaweed.

Based on some of the above which show that the waters in Luwu Regency and Palopo City have enormous potential for seaweed cultivation, it is very necessary for an integrated management effort so that it can maintain and improve both the production factors and the quality of seaweed in Luwu Regency and Palopo City. One way that can be used in the integrated management of water utilization businesses for seaweed cultivation is to find out how much the carrying capacity of water can support seaweed cultivation. The carrying capacity of the waters is needed to determine the optimum capacity of seaweed cultivation. Carrying capacity in this study includes how much land these waters which can be used optimally, large such waters can produce seaweed, as well as how many human resources that allow taking advantage of available land. By knowing the level of utilization and carrying capacity of water, it can be used as a foundation in the management of water so that the utilization rate does not exceed the existing carrying capacity.

Knowing how much carrying capacity of water that can be utilized for seaweed farming activities is very important for sustainable management. The approach that can be applied to determine the carrying capacity (carrying capacity) of waters in an effort to manage seaweed aquaculture in a sustainable manner in this study is the analysis of ecological footprint (EF) and mass balance of nitrate concentration $\left(\mathrm{NO}_{3}\right)$. The $\mathrm{EF}$ approach is based on the level of utilization of an existing aquatic resource and productivity (biocapacity/BC) (Bastianoni et al. 2013). The mass balance model approach to nitrate concentration is based on how large the availability of nitrate nutrients is able to support the growth of seaweed optimally on a certain land area. Research on the carrying capacity of waters and dynamic models of coastal management using the ecological footprint approach in Luwu Regency and Palopo City, as well as in the whole waters of Bone Bay, South Sulawesi has never been conducted. Therefore, the authors consider that the study of dynamic models and carrying capacity of the waters with the ecological footprint approach in Bone Bay is the first time carried out. 
The purpose of this study was to measure the carrying capacity of waters for Eucheuma cottonii seaweed cultivation, as well as model management of seaweed cultivation in Luwu Regency and Palopo City with the concept of Ecological Footprint (EF) analysis and mass balance nitrate concentration.

\section{METHOD}

\section{Time and Location of Research}

The research was conducted in two stages, namely, stage 1 was carried out in May 2015 (first transition season) and stage 2 in September 2015 (second transition season) in the coastal waters of Luwu Regency and Palopo City, Bone Bay, South Sulawesi. Primary data collection is carried out at 18 station points. The map of the research location is shown in Figure 1.

\section{Tool and Materials}

The tools used in this study are several tools for retrieving oceanographic parameter data namely thermometer, refractometer, $\mathrm{pH}$ meter, DO meter, current meter, Niskin bottle, icebox and several bottles of samples for storing seawater samples. While the material used was the seawater flow from HyCom+NCODA data in May and September 2015, NOAA imagery in 2004-2014 in the form of data on the distribution of sea surface temperature, the turbidity of water and chlorophyll-a content and questionnaire to obtain social primary data, economic and related stakeholders. Some of the stakeholders included the Head of the Maritime and Fisheries Agency (DKP), Kabid, Kasie and DKP staff in Luwu Regency and Palopo City, seaweed entrepreneurs and seaweed farmers, with a total of 30 respondents.

\section{Data}

The primary water data taken and analyzed in situ include seawater temperature, salinity, $\mathrm{pH}$, dissolved oxygen and current. Temperature and dissolved oxygen data were measured using DO meter, salinity using a refractometer, $\mathrm{pH}$ using a $\mathrm{pH}$ meter and current using a current meter and from HyCom+NCODA data in May and September 2015. Tidal secondary data came from Geospatial Information Bureau (2015), slope and length data the coastline comes from the DKP of Luwu Regency and Palopo City. Data analyzed in the laboratory of Brackish Water Aquaculture Research and Development Center, Maros, South Sulawesi included total suspended solids (TSS) data, chemical oxygen demand (COD), nitrate, phosphate, ammonia, chlorophyll-a, and heavy metals $\mathrm{Pb}, \mathrm{Cd}$, and $\mathrm{Hg}$. All water data was taken using poor bottles at a depth of 2 meters.

\section{Data analysis}

Data analysis was conducted to determine the carrying capacity of water that can be used for the cultivation of seaweed. Analysis of waters carrying capacity was carried out using the Ecological Footprint analysis (EF) approach and analysis of mass balance nitrate concentration $\left(\mathrm{NO}_{3}\right)$. The carrying capacity analysis of waters with $\mathrm{EF}$ approach includes three main components that must be known, namely: 1) how much the level of water use (in this case is the Ecological Footprint of production/EFP), 2) how much water space is available and the ability to produce (biocapacity /BC) seaweed, and, 3) how much resources humans who make it possible to utilize the available water space. By comparing the biocapacity to the Ecological Footprint, it will produce how much the carrying capacity of the waters. Analysis of waters carrying capacity based on mass balance nitrate concentration $\left(\mathrm{NO}_{3}\right)$ is based on how much nitrate concentration can support the growth of seaweed in water. 
Carrying capacity of waters with EF analysis approach (Wackernagel, 1994; Wackernagel and Rees, 1996; Rees, 1992; Rees, 1996) based on the results of conformity analysis using Geographic Information Systems (GIS), like according to the Prahasta (2002), which describes the carrying capacity of waters based on existing land suitability, but has not considered nutrients (especially nitrates) which are the main factors for seaweed growth. Thus a further analysis is needed to determine the actual carrying capacity of the waters by considering the availability of nutrients in an ecology, namely by approaching the mass balance nitrate concentration $\left(\mathrm{NO}_{3}\right)$. The difference between the results of carrying capacity extents EF with mass balance analysis of nitrate concentrations describes as a buffer area (buffer zone) to balance the nutrient supply to remain stable and sufficient for the cultivation of seaweed. The next analysis is to compile a dynamic model using the Stella version 9.0.2 program to know integrated coastal management models in the development of seaweed cultivation in Luwu Regency and Palopo City.

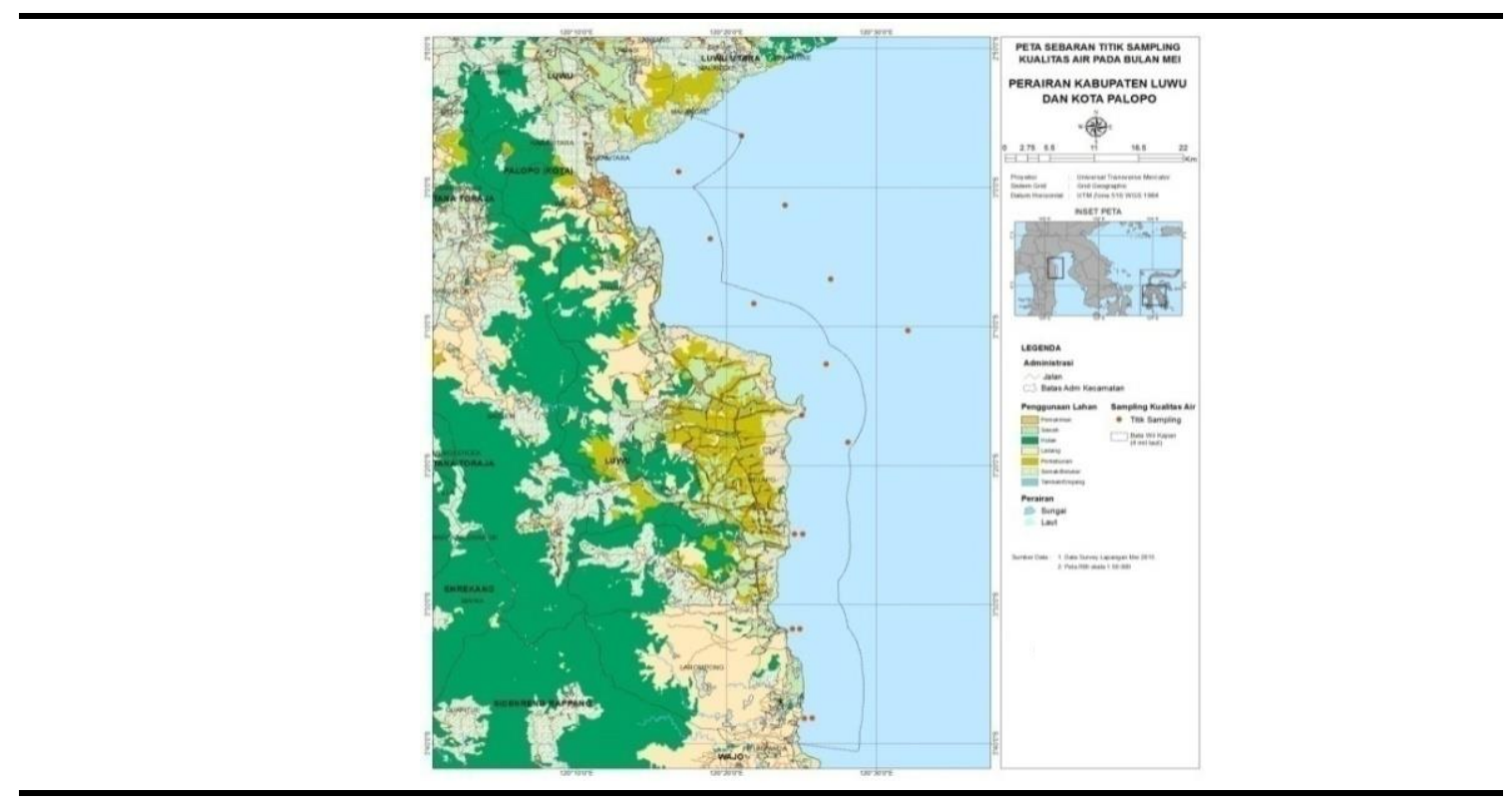

Figure 1. Map of the research location.

\section{Management Dynamic Model}

Making a dynamic model is done using the software Stella version 9.0.2. Creating a dynamic model of coastal area management with a special study on the development of seaweed cultivation is carried out in several stages, namely conceptual model, model formulation, model testing, and model implementation (Randers, 1980; Albin, 1997; Isee System, 2016; YSI Inc, 2006).

\section{Conceptual model}

The conceptual model starts with the identification of various needs to create a model so that it can produce a system operation that is considered effective. This step is done by looking for all the important factors that are very influential in the dynamic system.

\section{Model formulation}

Building a dynamic model aims to determine system behavior in assisting strategic planning in coastal area management in Luwu Regency and Palopo City.

a. Population submodel 
Population sub-models in the Luwu Regency and Palopo City are the function of the rate of population growth and the rate of decline in population. The rate of increase in population is influenced by immigration and birth. The rate of decline in population is influenced by emigration and death. Thus the total population at a certain time $(t)$ is:

Population $(t)=$ Population $(t-d t)+($ rate of increase-rate of decline $) x d t$

People who live in coastal areas will produce domestic waste that will enter the waters, where the waste that enters the waters is affected by the input fraction of waste into the water and the dilution of waste that occurs in the waters.

\section{b. Cultivated land area submodel}

The broad sub-model of cultivated water greatly affects the level of seaweed production, density, production per hectare and business capital. The water area is strongly influenced by the level of unused water area and water use. The level of land use is also influenced by the number of farmers and nurseries, while the unused water is affected by the unused water fraction.

\section{c. Seaweed production submodel}

The seaweed production sub-model is influenced by the level of seedling and the mortality rate of seaweed seedlings. The level of a nursery is strongly influenced by the fraction of the nursery, while the mortality rate of seaweed seedlings is influenced by wastewater entering the seaweed and the mortality fraction of seaweed seedlings.

\section{d. Carrying capacity submodel}

The waters carrying capacity sub-model is divided into two, namely carrying capacity based on Ecological Footprint (EF) and based on mass balance nitrate concentration. Several factors that affect the carrying capacity based on EF include the area of existing water area, the area of suitability, the number of cultivators, production and productivity of the waters as well as biocapacity. While carrying capacity that is based on mass balance nitrates include the volume of seawater that goes to the beach at high tide (Vo), the volume of seawater that comes out at low tide (Vs), the concentration of nitrate in (inflow), the concentration of nitrate exit (outflow), maximum nitrate inflow (MNI), maximum nitrate outflow (MNO), removal rate of nitrate $(\mathrm{R})$ and total nitrate loading (TNL).

\section{Model testing and implementation}

The dynamic model that has been built is then tested to determine the behavior of the system and to ensure that the model is truly by the objectives to be achieved. The model that is by the objectives then implemented to take policy from several alternatives.

\section{RESULTS AND DISCUSSION}

\section{Profile of Oceanography Parameters}

Parameters of seawater temperature very important for growing grass the sea. The average seawater temperature waters in Luwu Regency and Palopo City is $29.19^{\circ} \mathrm{C}$. Kawabe and Kawabe (1997) asserts that the most important factor for doing photosynthesis for algae is sun radiation and seawater temperature compared factor nutrient, where rate photosynthesis maximum on range temperatures of $24-30{ }^{\circ} \mathrm{C}$ (Glenn and Doty, 1981), 23-30 ${ }^{\circ} \mathrm{C}$ ( Mairth et al. 1995), 25-30 ${ }^{\circ} \mathrm{C}$ (Ding et al. 2013; Redmond, 2014) and photosynthesis will downhill on range temperatures of $35-40{ }^{\circ} \mathrm{C}$ (Glenn and Doty, 1981; Mairth et al. 1995), growth downhill on temperature in under $20^{\circ} \mathrm{C}$ (Mairth et al. 1995).

Salinity is a parameter that affects growth, uterus carrageenan and structure cellular on Eucheuam cottonii (Hayasi et al. 2010). According to Ding et al. (2013) stated that level growth highest on salinity 25-30\%, whereas according to Yong et al. (2013) optimum 
salinity for growth Eucheuma cottonii is $25-35 \%$. While carrageenan highest on salinity 25 $\%$ (Hayasi et al. 2010). Based on results analysis in the field to show that average salinity is $34.11 \%$. Based on Gazali (2013) stated that with salinity averages $33.69-34.53 \%$ accordingly for growth grass the sea Eucheuma cottonii.

The effect of $\mathrm{pH}$ of seawater very important for seaweed caused that $\mathrm{pH}$ is very influence levels of protein contained in seaweed (Tee et al. 2015). Growth at $\mathrm{pH} 8.4$ (as a control) has growth a daily high of $3.57 \mathrm{~cm} /$ day or $\pm 0.34 \% /$ day. While at extreme alkaline $\mathrm{pH}$ that is 9 points right growth daily is $2.44 \mathrm{~cm} /$ day or $\pm 0.42 \%$ / day and on condition acid with a pH of 6 growth daily reaching $0.61 \mathrm{~cm} /$ day or $\pm 0.07 \%$ /day (Tee et al. (2015). On generally range between 7.7-8.4 where $\mathrm{pH}$ is affected by a capacity buffer that is existence salt carbonate and bicarbonate contained in seawater (Nybakken, 1992). Based on Prema (2013) $\mathrm{pH}$ value of seawater usually on range 7.5 -8.5. Appropriate $\mathrm{pH}$ value for cultivation the sea is range between $7.8-8.4$. Based on results water analysis $\mathrm{pH}$ that an average of 7.80.

Current is the key factor to controls or influences the growth of seaweed. This play role important to prevent an increase in $\mathrm{pH}$ (caused by consumption of carbon dioxide) as well as function in supply nutrients in waters (Prema, 2013). Next based on Prema (2013) states that the optimum growth of Eucheuma cottonii happens on condition speed current \pm 20 $\mathrm{cm} /$ second. Based on Hurd et al. (1996) stated that speed current will influence process absorption nutrient, where rate absorption maximum on speed current 0.04-0.06 meters/second. Based on the results filed analysis, the average speed current is 0.14 meter/second. With so, with average speed current $0.13-0.15$ meters/second corresponding seaweed (Setiyanto et al. 2008).

Dissolved Oxygen (D)) considered one of the most important aspects of cultivation. If dissolved oxygen $<5 \mathrm{mg} / 1$ could to be excessive pressure on fish, and if up to $<2 \mathrm{mg} / 1$ could cause death on fish and organisms certain in waters (PHILMINAQ, 2006). Based on AMWQ (2008) states that the minimum concentration of dissolved oxygen in a safe sea for the life of an organism is $4 \mathrm{mg} / \mathrm{l}$. Based on results analysis showed that averages dissolved oxygen $6.32 \mathrm{mg} / 1$. The size change dissolved oxygen in the sea very influenced by change temperature, where more and more high temperatures then concentration dissolved oxygen more and more decreased (Sverdrup et al. 2004).

Chemical Oxygen Demand (COD) is defined as total oxygen is needed for oxidizing particulates material dissolved in water, where COD is indicator practical concentration from ingredients organic and water quality (Kawabe and Kawabe, 1997). It in line with statement Shanmugam et al. (2006) that COD is the total amount of oxygen required for oxidizing all organic material to be carbon dioxide (CO2) and water through process oxidation chemistry. Samawi (2007) to explain that COD is a lot of oxygen that is needed for oxidizing all over ingredients organic, both easy explained nor difficult decompose. Material organic easy explained generally originated from waste domestic or settlement, while the difficult one decomposes generally originated from waste industry, mining and agriculture. With this big small COD concentration can be made into indicator pollution something waters, as expressed by Zang et al. (2015) that Chemical Oxygen Demand (COD) is a combined indicator for measure level pollution caused by ingredients organic in seawater. Based on the analysis of the results to show that the average COD is $494.51 \mathrm{mg} / 1$. According to KLH (1988) states that limit safe COD in the water is $\leq 40 \mathrm{mg} / 1$. The COD is a high possibility caused there are ingredients very organic difficult for described by bacteria in waters. As explained by Boyd (1990) that Chemical Oxygen Demand (COD) is the total oxygen needed for parse all over ingredients organic contained in water.

Total solid refers to any material either suspended or dissolved in seawater. All something being held back by the filter is considered as solids suspended, while the one passing through the filter is classified as solids dissolved, i.e. usually sized $0.45 \mu \mathrm{m}$. Both materials are concentrated in water called as Total Suspended Solids (TSS) and Total Dissolved Solid (TDS) (APHA, 1998). Sastrawijaya (2000) stated that deep TSS 
concentration waters generally composed of phytoplankton, zooplankton, waste activity human, mud, and waste industry. Solid material suspended in waters natural not is nature poison, will but if the amount excessive could improve value turbidity hereinafter inhibit penetration light sun to the water column. Based on AMWQ (2008) that limit safe TSS against organisms in the sea is allowed enhancement maximum of $10 \%$ of seasonal average concentration, whereas according to PHILMINAQ (2006) states that limit safe TSS concentration for an organism in the sea is $<10 \mathrm{mg} / 1$. Results analysis to show that the average TSS is $27.53 \mathrm{mg} / 1$.

Seaweed needs various kinds of nutrients used in the growth process. Nitrogen and Phosphor are two nutrients that limit the growth of seaweed (Harrison and Hurd, 2001). Based on Hurd et al. (2014) invoke that there is an element nutrient that is made factor delimiter for growth and breeding of seaweed. The most important limiter factor is an element of nitrogen $(\mathrm{N})$, then is phosphorus $(\mathrm{P})$ as well as substance iron $(\mathrm{Fe})$. Third element nutrients contained in waters that very influence biology activity. This is marked that concentrations of N, P and Fe in the network are 104 to 105 more bigger of the concentration in sea water. Fong and Paul (2011) explain that there are very main parameters influence growth and abundance macroalgae (seaweed) on all ecosystem that is availability nutrient especially nitrogen $(\mathrm{N})$ and phosphorus $(\mathrm{P})$ as well factor power herbivores. Nutrients $(\mathrm{N}$ and $\mathrm{P})$ are factor delimiter in primary productivity at almost every ecosystem in all over the world (Harpole et al. 2011). So too as described by Alstyne (2000) stated that nutrient such as nitrogen $(\mathrm{N})$, phosphorus $(\mathrm{P})$ and substance iron $(\mathrm{Fe})$ is factor delimiter for growth macroalgae and phytoplankton at the sea. Concentration nitrate the average is $0.58 \mathrm{mg} / 1$. If partner $t$ too high will impact growth grass the sea because it brings up the algae as competitors in getting nutrition. Based on Decision State Minister of Environment Life number 51 of 2004 concerning raw quality, concentration maximum nitrate is $0.008 \mathrm{mg} / 1$, and or $0.06 \mathrm{mg} / 1$ (AMWQ, 2008), or $0.02 \mathrm{mg} / 1$ (PHILMINAQ, 2006). Average concentration phosphate reaching $0.38 \mathrm{mg} / \mathrm{l}$. Based on AMWQ (2008) explained that standard limit secure for living organisms in the sea and health human to concentration phosphate is $15 \mu \mathrm{g} /$ liter $(0.015 \mathrm{mg} / \mathrm{l})$ (at the coast), and or $0.05 \mathrm{mg} / 1$ (PHILMINAQ, 2006). Based on Decision State Minister of Environment Life number 51 of 2004 concerning raw quality, concentration maximum decent phosphate $0.015 \mathrm{mg} / 1$ for marine life. Results analysis Ammonia concentration on average was $0.17 \mathrm{mg} / 1$. Based on AMWQ (2008) explained that standard limit secure for living organisms in the sea and health human to concentration ammonia (NH3) is $70 \mu \mathrm{g} /$ liter $(0.07 \mathrm{mg} / 1)$, and or $0.02 \mathrm{mg} / 1$ (PHILMINAQ, 2006).

\section{Suitability of Waters for Seaweed}

To determine the suitability of waters in Luwu Regency and Palopo City for the cultivation of Eucheuma cottonii seaweed, an overlay of several oceanographic parameters was carried out. However, before doing an overlay, scoring and weighting of each of these parameters are first performed for each suitability criterion. Furthermore, an overlay of each of these parameters is performed to obtain a water suitability map using software ArcGIS version 10 . Scoring data and weighting of sea level suitability are shown in Table 1.

Table 1 . Suitability matrix Eucheuma cottonii.

\begin{tabular}{lllllrrr}
\hline No & Parameter & Unit & Suitability & Range & Score & $\begin{array}{l}\text { Weight } \\
(\%)\end{array}$ & $\begin{array}{l}\text { Total } \\
\text { value }\end{array}$ \\
\hline 1 & Phosphate & $\mathrm{mg} / 1$ & $\mathrm{~S} 1$ & $0,2-0,5$ & 30 & & 420 \\
& & & $\mathrm{~S} 2$ & $0,1-0,2 \& 0,5-1$ & 20 & 8 & 280 \\
& & $\mathrm{~N}$ & $<0,1 \&>1$ & 10 & & 140 \\
2 & \multirow{2}{*}{ Nitrate } & $\mathrm{mg} / 1$ & $\mathrm{~S} 1$ & $0,9-3,2$ & 30 & & 420 \\
& & $\mathrm{~S} 2$ & $0,1-<0,9 \& 3,3-3,4$ & 20 & 10 & 280 \\
& & $\mathrm{~N}$ & $<0,1 \&>3,4$ & 10 & & 140 \\
\hline
\end{tabular}




\begin{tabular}{|c|c|c|c|c|c|c|c|}
\hline No & Parameter & Unit & Suitability & Range & Score & $\begin{array}{l}\text { Weight } \\
(\%)\end{array}$ & $\begin{array}{l}\text { Total } \\
\text { value }\end{array}$ \\
\hline \multirow[t]{3}{*}{3} & Ammoniac & $\mathrm{mg} / 1$ & S1 & $<0,3$ & 30 & & 150 \\
\hline & & & S2 & $0,3-0,5$ & 20 & 5 & 100 \\
\hline & & & $\mathrm{N}$ & $>0,5$ & 10 & & 50 \\
\hline \multirow[t]{3}{*}{3} & Current & $\mathrm{m} / \mathrm{s}$ & S1 & $0,2-0,3$ & 30 & & 300 \\
\hline & & & S2 & $0,1-0,2 \& 0,3-0,4$ & 20 & 10 & 200 \\
\hline & & & $\mathrm{N}$ & $<0,1 \&>0,4$ & 10 & & 100 \\
\hline \multirow[t]{3}{*}{4} & Temperature & $\mathrm{oC}$ & S1 & $24-30$ & 30 & & 240 \\
\hline & & & S2 & $20-24$ & 20 & 8 & 160 \\
\hline & & & $\mathrm{N}$ & $<20 \&>30$ & 10 & & 80 \\
\hline \multirow[t]{3}{*}{5} & Salinity & $\%$ o & S1 & $30-32$ & 30 & & 390 \\
\hline & & & S2 & $22-30 \& 32-34$ & 20 & 12 & 260 \\
\hline & & & $\mathrm{N}$ & $<22 \&>34$ & 10 & & 130 \\
\hline \multirow[t]{3}{*}{6} & $\mathrm{pH}$ & & S1 & $6,5-8,5$ & 30 & & 240 \\
\hline & & & S2 & $4-6,5 \& 8,5-9,5$ & 20 & 5 & 160 \\
\hline & & & $\mathrm{N}$ & $<4 \&>9,5$ & 10 & & 80 \\
\hline \multirow[t]{3}{*}{7} & $\mathrm{DO}$ & $\mathrm{mg} / 1$ & S1 & $>6$ & 30 & & 150 \\
\hline & & & $\mathrm{S} 2$ & $4-6$ & 20 & 5 & 100 \\
\hline & & & $\mathrm{N}$ & $<4$ & 10 & & 50 \\
\hline \multirow[t]{3}{*}{8} & COD & $\mathrm{mg} / 1$ & S1 & $10-90$ & 30 & & 150 \\
\hline & & & S2 & $91-100$ & 20 & 3 & 100 \\
\hline & & & $\mathrm{N}$ & $>100$ & 10 & & 50 \\
\hline \multirow[t]{3}{*}{9} & Chlorophyll-a & $\mathrm{mg} / 1$ & S1 & $3,5-10$ & 30 & & 150 \\
\hline & & & S2 & $0,2-<3,5$ & 20 & 2 & 100 \\
\hline & & & $\mathrm{N}$ & $<0,2$ & 10 & & 50 \\
\hline \multirow[t]{3}{*}{10} & Turbidity & NTU & S1 & $\leq 10$ & 30 & & 240 \\
\hline & & & S2 & $<10-<40$ & 20 & 7 & 160 \\
\hline & & & $\mathrm{N}$ & $>40$ & 10 & & 80 \\
\hline \multirow[t]{3}{*}{11} & Distance from & $\mathrm{m}$ & S1 & $150-1500$ & 30 & & 150 \\
\hline & & & S2 & $1200-2000$ & 20 & 5 & 100 \\
\hline & & & $\mathrm{N}$ & $>2000$ & 10 & & 50 \\
\hline \multirow[t]{3}{*}{12} & Depth & $\mathrm{m}$ & S1 & $2-15$ & 30 & & 420 \\
\hline & & & S2 & $16-20$ & 20 & 14 & 280 \\
\hline & & & $\mathrm{N}$ & $>20$ & 10 & & 140 \\
\hline Tot & & & & & & 100 & \\
\hline
\end{tabular}

To better reflection and describe the suitability of the waters for Eucheuma cottonii seaweed cultivation for 1 year, which is a combined representative of the $1^{\text {st }}$ transition season and the 2nd transition, then overlay the suitability maps of the 2 seasons were carried out. This is done so that it can be used as a basis for making policies both by the Regional Government and or related stakeholders in determining which locations are truly safe and very suitable for seaweed cultivation. Some reasons for consideration in making policy for determining the appropriate location for seaweed cultivation include that if the seaweed cultivation community can adapt to seasonal changes followed by changes in location and suitability of cultivated water area, the farming community can cultivate in a very suitable location and suitable for each season. However, if the cultivation community is unable to adapt to seasonal changes, the farmers are advised to choose a location that is truly safe and very suitable for seaweed cultivation, namely the location of the combined suitability of the 1 st transition season and $2^{\text {nd }}$ transition.

Based on the results of a combined analysis of suitability from the 1st transition season and $2^{\text {nd }}$ transition, a suitability map is produced that reflects the representative suitability in 1 year. Based on the results of the analysis show that in general, the waters in Palopo City and most of the waters of northern Luwu are not suitable for seaweed cultivation. While in 
the southern part of Luwu Regency waters are generally suitable for seaweed cultivation, but specifically in South Ponrang Sub Regency, it is very suitable for seaweed cultivation. The area of water in Luwu Regency with a very suitable category (S1) is 13,618.85 hectares, the appropriate category (S2) is 46,882.26 hectares and the inappropriate category (N) is 9,089.49 hectares. If assuming the very appropriate (S1) and appropriate (S2) categories are combined into appropriate and suitable waters for seaweed, then the appropriate total area is 60,501.11 hectares. Also, based on the location of the MPA plan in Luwu Regency with an area of 280.48 hectares, where the Marine Protected Area DPL is included in the area with the appropriate category (S2), the area of very suitable fixed category is $13,618.85$ hectares, the corresponding category being $46,162.94$ hectares, so that the total area that is feasible and in accordance after deducting the DPL area becomes 59,781.79 hectares.

Table 2 . Suitability of waters in Luwu Regency and Palopo City.

\begin{tabular}{lllll}
\hline \multirow{2}{*}{ No } & \multirow{2}{*}{ Criteria } & \multicolumn{2}{l}{ Area aquatic (Ha) } & \\
\cline { 3 - 5 } & & Luwu Regency & & Palopo City \\
& & Initial area & Area minus MPA1 & - \\
\hline 1 & Very suitable (S1) & $13,618.85$ & $13,618.85$ & $1,771.41$ \\
2 & Suitable (S2) & $46,882.26$ & $46,162.94$ & $6,941.33$ \\
3 & Not suitable (N) & $9,089.49$ & $9,089.49$ & $1,771.41$ \\
\hline \multicolumn{2}{l}{ Total (S1+S2) } & $60,501.11$ & $59,781.79$ & \\
\hline \multicolumn{2}{l}{ Area of MPA $=280.48$ ha } & & & \\
\hline
\end{tabular}

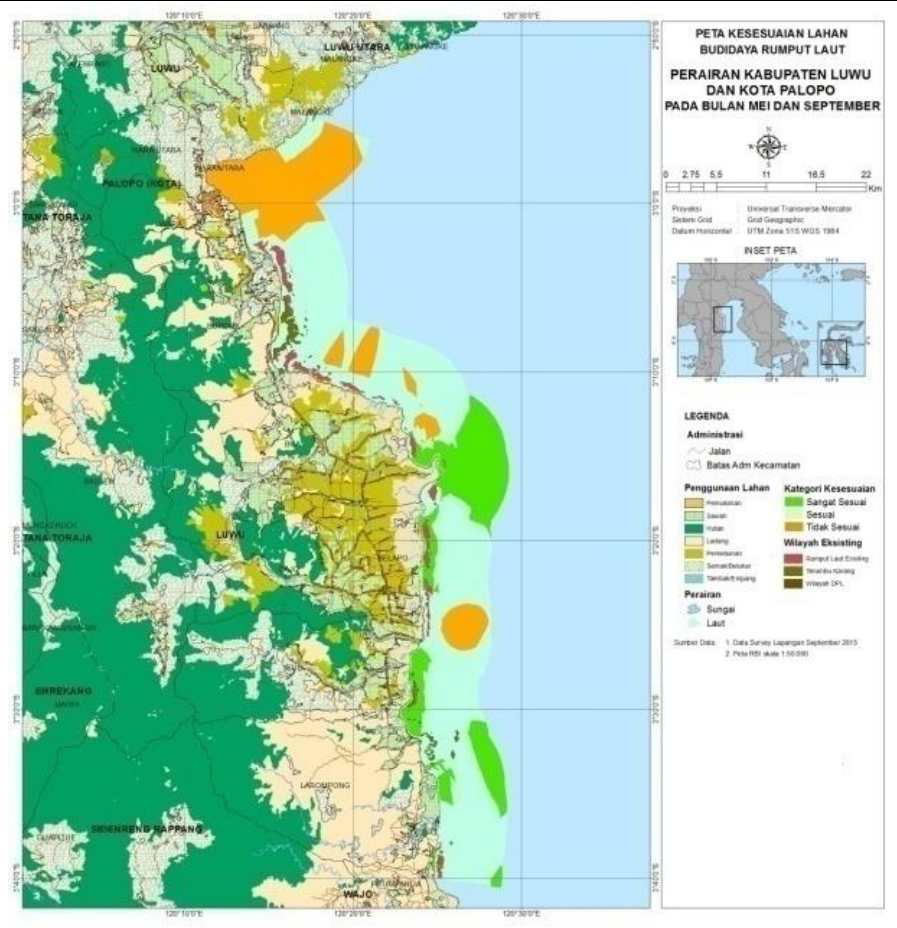

Figure 3. Extent of suitability of aquatic in Luwu Regency and Palopo City.

The area of water in Palopo City with a very suitable category (S1) is 0 hectares, the appropriate category (S2) is 1,771.41 hectares and does not match (N) 6,941.33 hectares. If assuming the very appropriate (S1) and appropriate (S2) categories are combined into appropriate and suitable waters for seaweed, then the corresponding total area is 1,771.41 hectares. Data on water suitability results are presented in Table 2 and Figure 2. 


\section{Utilization of Water Spaces}

Analysis of the use of water space for seaweed cultivation in Luwu Regency and Palopo City was carried out using the Ecological Footprint approach. The Ecological Footprint (EF) analysis is an analysis that states a productive ecological area to provide marine resources as a supply of consumption for residents in the area concerned (Adrianto, 2010). In other words, the Ecological Footprint analysis is the total area needed to support a population and/or certain activities. The EF analysis can also determine how much of the resources that can be produced (Ecological Footprint Productions/EFP) pitch toward the available land area. The EF analysis in this study is an analysis of Ecological Footprint Production (EFP) which describes the total amount of resources produced (Eucheuma cottonii seaweed production) on the existing water area.

The production of Eucheuma cottonii seaweed in Luwu Regency and Palopo City starting in 2008-2014 tended to increase, but the number of fish farmers in the two regions showed a different trend. The number of cultivators in Luwu Regency increases every year, but in Palopo City tends to decline. Based on production data and the number of cultivators, EFP can be calculated for each of these regions.

The EFP value of seaweed in Luwu Regency shows that waters with an average area of existing utilization of 9,709.24 hectares and utilized by seaweed farmers as many as 3,472 capita, the waters are capable of producing seaweed production (EFP) of 67.8883 tons/capita/year. Likewise with EFP in Palopo City with an average land area of 438.61 hectares and utilized by seaweed farmers as much as 1,503 capita, these waters produce seaweed (EFP) as much as 3.0876 tons/capita/year. The EFP values in Luwu Regency are higher than in Palopo City due to high production levels and wider cultivation land. With wider land has the opportunity and potential to produce more seaweed production. The results of the analysis of EFP Luwu and Palopo presented in Table 3.

\section{Availability of Aquatic Space (Biocapacity)}

The availability of water space (Biocapacity/BC) for Eucheuma cottonii seaweed cultivation in Luwu Regency and Palopo City will illustrate two main components, namely 1) how much of the entire waters are capable of supporting seaweed cultivation, and, 2) how big is the product seaweed that can be achieved (assuming overall use of available water).

Biocapacity analysis is based on the suitability of the waters that support seaweed cultivation. To determine the suitability of aquatic spaces that can be used spatially seaweed cultivation using the concept of land suitability evaluation. This concept is based on physical, chemical and aquatic biology parameters which are ecologically feasible prerequisites for seaweed cultivation. For this reason, a Geographic Information System (GIS) technique is used to determine the area of waters suitable for seaweed cultivation in Luwu Regency and Palopo City. Spatially, the waters of Luwu and Palopo for the development of seaweed Eucheuma cottonii right grouped into three categories namely very appropriate class (S1), appropriate (S2) and is not suitable (N).

Biocapacity calculations in this study divided into partial biocapacity (based on each category of S1 and S2 classes) and total biocapacity (total area of aquatic from the S1 and S2 classes). Based on the biocapacity analysis in the waters of Luwu Regency, the results showed that the waters in the very appropriate category (S1) were 327,539.62 tons and the corresponding category (S2) was 1,110,239.98 tons. If assuming the S1 and S2 categories are combined, the total biocapacity reaches $1,437,779.60$ tons, which means that assuming the utilization of all available water is $59,781.79$ hectares, then the waters are capable of producing seaweed production of 1,437,779.60 ton/year. 
Tabel 3. Ecological Footprint production of Eucheuma cottonii in Luwu Regency dan Palopo City.

\begin{tabular}{lllllclc}
\hline \multirow{2}{*}{ No } & Year & \multicolumn{2}{c}{ Cultivator (capita) } & \multicolumn{2}{c}{ Production (Ton/year) } & \multicolumn{2}{c}{ EFP (Ton/capita/year) } \\
\cline { 3 - 7 } & & Luwu & Palopo & Luwu & Palopo & Luwu & Palopo \\
& & Regency & City & Regency & City & Regency & City \\
\hline 1 & 2008 & 3,456 & 1,543 & $174,875.44$ & $2,195.51$ & 50.6005 & 1.4229 \\
2 & 2009 & 3,465 & 1,569 & $178,361.34$ & $2,219.83$ & 51.4751 & 1.4148 \\
3 & 2010 & 3,473 & 1,578 & $183,202.80$ & $2,227.04$ & 52.7506 & 1.4113 \\
4 & 2011 & 3,476 & 1,464 & $229,017.00$ & $3,416.25$ & 65.8852 & 2.3335 \\
5 & 2012 & 3,476 & 1,479 & $256,257.85$ & $6,416.00$ & 73.7221 & 4.3381 \\
6 & 2013 & 3,479 & 1,479 & $272,667.60$ & $12,543.00$ & 78.3753 & 8.4807 \\
7 & 2014 & 3,480 & 1,407 & $356,385.50$ & $3,112.31$ & 102.4096 & 2.2120 \\
\hline \multicolumn{2}{l}{ Average } & 3,472 & 1,503 & $235,823.93$ & $4,589.99$ & 67.8883 & 3.0876 \\
\hline
\end{tabular}

Biocapacity is the waters of Palopo City showed that the waters with the very appropriate category (S1) were 0 tons, while in the appropriate category (S2) was 18,287.46 tons. If assuming the S1 and S2 categories are combined, the total biocapacity in Palopo City reaches $18,287.46$ tons, which means that assuming the utilization of all available land is $1,771.41$ hectares, the waters are capable of producing seaweed production as much as $18,287.46$ ton/year. The biocapacity analysis results are shown in Table 4 .

Table 4. Water Biocapacity di Luwu Regency dan Palopo City.

\begin{tabular}{|c|c|c|c|c|c|c|c|c|}
\hline \multirow{3}{*}{ Season } & \multicolumn{4}{|c|}{ Luwu Regency } & \multicolumn{4}{|c|}{ Palopo City } \\
\hline & \multirow{2}{*}{$\begin{array}{c}\text { Productio } \\
\text { n (Ton)1 }\end{array}$} & \multicolumn{2}{|c|}{ BC Partial (Ton) } & \multirow{2}{*}{$\begin{array}{l}\text { BC Total } \\
\text { (Ton) }\end{array}$} & \multirow{2}{*}{$\begin{array}{l}\text { Productio } \\
\text { n (Ton) }\end{array}$} & \multicolumn{2}{|c|}{ BC Partial (Ton) } & \multirow{2}{*}{$\begin{array}{l}\text { BC Total } \\
\text { (Ton) }\end{array}$} \\
\hline & & $\mathrm{S} 1$ & $\mathrm{~S} 2$ & & & $\mathrm{~S} 1$ & $\mathrm{~S} 2$ & \\
\hline $1 \mathrm{st}$ & & $569,061.8$ & $575,685,06$ & $1,144,746.8$ & & $15,232.4$ & $41,017.0$ & $56,249.5$ \\
\hline Transitio & & 0 & & 6 & & 8 & 9 & 6 \\
\hline $\begin{array}{l}\mathrm{n} \\
\text { 2nd } \\
\text { Transitio } \\
\mathrm{n}\end{array}$ & $235,823.93$ & $\begin{array}{c}387,802.6 \\
2\end{array}$ & $867,751.21$ & $\begin{array}{c}1,255,553.8 \\
3\end{array}$ & $4,589.99$ & 0 & 1.66 & 1.66 \\
\hline $\begin{array}{ll}\text { Total } & 2 \\
\text { season } & \end{array}$ & & $32,539.62$ & $\begin{array}{c}1,110,239.9 \\
8\end{array}$ & $\begin{array}{c}1,437,779.6 \\
0\end{array}$ & & 0 & $\begin{array}{c}18,287.4 \\
6\end{array}$ & $\begin{array}{c}18,287.4 \\
6\end{array}$ \\
\hline
\end{tabular}

\section{Water Carrying Capacity}

Carrying capacity of waters is the ability of a system to support activities at a certain level (UNEP, 1996), in this case, is the cultivation of seaweed species Eucheuma cottonii . In other words, carrying capacity is related to the coastal area system which has certain limits or has a threshold for an activity (MacLeod and Cooper, 2005).

\section{Water Carrying Capacity based on Ecological Footprint (EF) Analysis}

To find out the carrying capacity of a waters based on the analysis of ecological footprint (EF), three main components must be known, namely: 1) how much the level of water utilization (in this case ecological footprint production/EFP), 2) how much space is available waters (Biocapacity/BC) that can support these activities, as well as, 3 ) how much amount of human resources (capita) makes it possible to utilize the available water space. By comparing the biocapacity to the ecological footprint, it will produce how much the carrying capacity of the waters.

Based on the results of the analysis of the water carrying capacity in Luwu Regency shows that the level of water utilization (EFP) is 67.8883 tons/capita $(235,823.93$ tons/year), while the availability of water space (Biocapacity/BC) is $59,781.79$ hectares which is capable of producing seaweed as much as 1,437,779.60 tons/year. When using the assumption that the utilization of all available water lands $(59,781.79$ hectares), then the carrying capacity of the number of human resources that are possible to be able to utilize the water is 21,432 capita. 
The water carrying capacity in Palopo City shows that the level of water utilization (EFP) is 3.0876 tons/capita (4,589.99 tons/year), while the availability of water space (Biocapacity/BC) is 1,771.41 hectares which is capable of producing seaweed as much as $18,287.46$ tons/year. When using the assumption that the utilization of all available water lands (1,771.41 hectares), the carrying capacity of the number of human resources that are likely able to utilize the water area is 635 capita. The results of the analysis of waters carrying capacity are presented in Table 5.

Tabel 5. Water Carrying Capacity Based on Ecological Footprint Analysis for Eecheuma Cottonii Seaweed in Luwu and Palopo Regency.

\begin{tabular}{lllllll}
\hline & \multicolumn{2}{l}{ Luwu Regency } & Palopo City & \\
\cline { 2 - 7 } Season & $\begin{array}{l}\text { EFP } \\
\text { (Ton/capita) }\end{array}$ & BC (Ton) & $\begin{array}{l}\text { Carrying } \\
\text { capacity } \\
\text { (capita) }\end{array}$ & $\begin{array}{l}\text { EFP } \\
\text { (Ton/capita) }\end{array}$ & BC (Ton) & $\begin{array}{l}\text { Carrying } \\
\text { capacity } \\
\text { (capita) }\end{array}$ \\
\hline 1st Transition & & $1,144,746.86$ & 17,064 & & $56,249.56$ & 1,954 \\
2nd Transition & 67.8883 & $1,255,553.83$ & 18,716 & 3.0876 & 1.66 & $0.60 \approx 1$ \\
Total 2 season & & $1,437,779.60$ & 21,432 & & $18,287.46$ & 635 \\
\hline
\end{tabular}

\section{Carrying Capacity based on Mass Balance Total Nitrate Concentration Model.}

Water carrying capacity based on mass balance total nitrate concentration $\left(\mathrm{NO}_{3}-\mathrm{N}\right)$, which explains that in the case of the growth of seaweed. If the supply and availability of water are insufficient for growth with a certain area of cultivation, likely, seaweed production will not be optimal. Thus, it is necessary to support the growth and production of seaweed. In the analysis of the waters carrying capacity based on the mass balance model using nitrate parameters as the main key factor to determine the carrying capacity of the waters. This is the most important material for photosynthesis.

The analysis of water carrying capacity based on mass balance nitrate concentration, several main factors play a role in determining the ability to support a healthy cultivation business. Nitrate concentration in the water mass at high tide and low, how much nitrate concentration enters and exits the water, and it will affect the availability of nitrate loading (Widigdo dan Pariwono, 2003).

\section{The volume of Seawater Mass at pairs (Vo) and Low (Vs)}

Based on the results of the show the average height in the waters of Luwu Regency is 1.5 meters with a frequency of 2 times/day, with a coastline length reaching $116,161 \mathrm{~km}$ and the beach slope average is 3 degrees. In the presence of tidal waves (tide) will affect the frequency of inundation of water. At the time of receding, the distance from the coastline at low tide to the minimum depth of 2 meters towards the sea is an average of 350 meters. The 2-meter depth limit is a benchmark for the minimum suitability of depth and the rate of fishing boats for cultivation mobility. Based on the analysis of the volume of water mass at tide (Vo ) in Luwu Regency is $61.901,286.10 \mathrm{~m} 3$, and the volume of water mass at low tide is $60,111,988.69 \mathrm{~m} 3$.

The tidal type in Palopo City is the same as in Luwu Regency, which is a semi-annual type, with a non-average height of 1.5 meters with a frequency of 2 times/day. The coastline length in Palopo City is $25 \mathrm{~km}$ and the coast slope is on average 3 degrees. The distance from the beach at low tide is the minimum limit of 2 meters towards the sea is 200 meters on average. Thus the calculation of the volume of water mass at the time of tide (Vo) in Palopo City is 7,697,303.98 $\mathrm{m} 3$ and the time of low tide was 7,312,214.01 $\mathrm{m} \mathrm{3}$. By knowing the mass of water at the time of tide (Vo) and low tide (Vs) it can be used as a basis for the supply of nitrates and the dilution process of waste that is in the sea. 


\section{Total Nitrate Inflow (TNI), Total Nitrate Outflow (TNO) and Removal Rate}

Nitrate inflow into the water (nitrate inflow) at the time of tide and out at low tide (outflow nitrate) will determine the rate of loss of nitrate concentration (removal rate) in the waters. The size of the nitrate inflow and nitrate outflow is also strongly influenced by the volume of water mass during tide (Vo) and low tide (Vs). Based on the calculation that the inflow of nitrate in Luwu Regency was $75,767,174.18 \mathrm{~kg}$ /day and nitrate outflow was $73,577,074.15 \mathrm{~kg} /$ day, the removal rate of nitrate was $0.97 \mathrm{~kg} /$ day. Whereas in the waters of Palopo City the inflow value of nitrate was $9,421,500.07 \mathrm{~kg} /$ day and the nitrate outflow was $8,950,149.95 \mathrm{~kg} /$ day, so the removal rate of nitrate was $0.95 \mathrm{~kg} /$ day.

\section{Maximum Nitrate Inflow (MNI) and Maximum Nitrate Outflow (MNO)}

The maximum value of nitrate inflow is strongly influenced by the volume of sea mass at high tide (Vo) and nitrate concentration based on the quality standard at sea $(\mathrm{Cb})$. While the maximum value of nitrate outflow is influenced by the removal rate and the maximum value of nitrate inflow. This study using the optimum nitrate standard for seaweed-based on Aslan (1998) which is equal to $0.3 \mathrm{mg} / 1$. Based on the calculation results, the maximum value of nitrate inflow in the waters of Luwu Regency is $66,853,388.98 \mathrm{~kg} /$ day and the maximum nitrate outflow is $64,920,947.78 \mathrm{~kg} /$ day. While the maximum nitrate inflow in Palopo City is $8,313,088.30 \mathrm{~kg} /$ day and the maximum nitrate outflow is $7,897,191.14$ $\mathrm{kg} /$ day.

\section{Total Nitrate Loading (TNL) and Water Carrying Capacity}

The availability of total nitrate (total nitrate loading) is strongly influenced by total nitrate concentration and total nitrate concentration (total nitrate outflow) on the area of existing seaweed cultivation. The existing area of the average seaweed cultivation area in Luwu Regency is 9,709.24 hectares and in Palopo City is 438.61 hectares. Thus the total nitrate of loading in the waters of Luwu Regency is $225.57 \mathrm{~kg} / \mathrm{ha} /$ day, while the total nitrate loading in the waters of Palopo City is $1,074.65 \mathrm{~kg} / \mathrm{ha} /$ day.

Based on some calculations of reviews these variables, it can be known the water carrying capacity based on the mass balance of nitrate concentration able to support seaweed cultivation. The flow rate is influenced by how much nitrate outflow is and the maximum nitrate outflow to the total supply of nitrate in the water (total nitrate outflow). Thus the waters that can be utilized for cultivation in Luwu Regency are 38,374.69 hectares and the maximum area that can still be tolerated is $48,083.93$ hectares. Whereas the watershed can be utilized for cultivation in Palopo City is 979.82 hectares and the maximum limit that can be tolerated is $1,418.43$ hectares. The results of the calculation of the carrying capacity of the waters based on concentration Mass Balance are shown in Table 6.

Table 6. Water Carrying Capacity Based on Mass Balance Nitrat.

\begin{tabular}{|c|c|c|c|}
\hline Parameter & Unit & $\begin{array}{l}\text { Luwu Regency } \\
\text { Value }\end{array}$ & $\begin{array}{l}\text { Palopo City } \\
\text { Value }\end{array}$ \\
\hline Tidal mass volume (Vo) & $\mathrm{m} 3$ & $61,901,286.10$ & $7,697,303.98$ \\
\hline Low tide mass volume (Vs) & $\mathrm{m} 3$ & $60,111,988.69$ & $7,312,214.01$ \\
\hline Total nitrat inflow (TNI) & $\mathrm{kg} /$ day & $75,767,174.18$ & $9,421,500.07$ \\
\hline Total nitrat outflow (TNO) & $\mathrm{kg} /$ day & $73,577,074.15$ & $8,950,149.95$ \\
\hline Removal rate nitrat $(\mathrm{R})$ & $\mathrm{kg} /$ day & 0.97 & 0.95 \\
\hline Maximum nitrat inflow (MNI) & $\mathrm{kg} /$ day & $66,853,388.98$ & $8,313,088.30$ \\
\hline Maximum nitrat outflow (MNO) & $\mathrm{kg} /$ day & $64,920,947.78$ & $7,897,191.14$ \\
\hline Total nitrat loading (TNL) & $\mathrm{kg} / \mathrm{ha} /$ day & 225.57 & $1,074.65$ \\
\hline Water carrying capacity (CC) & ha & $38,374.69$ & 979.82 \\
\hline Maximum carrying capacity (MCC) & ha & $48,083.93$ & $1,418.43$ \\
\hline
\end{tabular}




\section{Combination Carrying Capacity based on EF and Mass Balance Nitrate}

\section{Water Carrying Capacity in Luwu Regency}

Luwu Regency based on the ecological footprint (EF) shows that the total area that can be utilized for seaweed cultivation is $59,781.79$ hectares. While the capacity based on mass balance nitrate is $38,374.69$ hectares, there is a difference in the area of $21,407.10$ hectares. If it will make use of the extent that it can be tolerated by water, then the maximum area is $48,083.93$ hectares, so that there is a difference in the area of $11,697.86$ hectares. This difference is used as a buffer zone so that the supply and availability of nutrients for seaweed growth are maintained. In other words, from the available area (based on EF analysis), only $64.19 \%$ (maximum $80.43 \%$ ) which can be utilized optimally for the cultivation locations, while the rest is as a buffer zone.

Based on the analysis of mass balance nitrate in Luwu Regency waters, the water carrying capacity covering $38,374.68$ hectares is capable of producing seaweed (biocapacity) as much as $922,928.96$ tons and human resources to the which can make use of the area for seaweed cultivation of 13.595 people (capita). The maximum area of 48,083.93 tons of seaweed and human resources will enable it to be extended by the waters, which can enable it to utilize 17,034 people for seaweed cultivation (capita).

\section{Water Carrying Capacity in Palopo City}

The results of the watershed in Palopo City are based on the ecological footprint (EF), which shows that the total area that can be used for cultivation is 1,771.41 hectares. The current capacity based on mass balance nitrate is 979.82 hectares, so there is a difference in the area of 791.59 hectares. If it will make use of the waters that are still tolerable, the maximum area is $1,418.43$ hectares, so that there is a difference in the area of 352.98 hectares. This difference is used as a buffer zone so that the supply and availability of growth in Palopo City are maintained. In other words, available area (based on EF analysis), only $55.31 \%$ (maximum $80.07 \%$ ) can be used as optimally for seaweed cultivation locations, while the remainder is the buffer zone.

Based on the analysis of mass balance nitrate in the waters of Palopo City, the water carrying capacity covering an area of 979.82 hectares is capable of producing seaweed (biocapacity) of 10,115.34 tons and human resources can use of the area of 3,276 seaweed cultivation (capita). If we will use the maximum to the extent that can still be tolerated by water carrying capacity, the maximum area is $1,418.43$ hectares and can be produced as much as 14,643.41 tons and human resources that can enable the use of the area for seaweed cultivation of 4,743 people (capita). The combination results of the water carting capacity based on EF and mass balance nitrate analysis are shown in Table 7.

Table 7. The Combination Carrying Capacity based on EF and Mass Balance Nitrate

\begin{tabular}{|c|c|c|c|c|c|c|}
\hline \multirow[b]{2}{*}{$\begin{array}{l}\text { Carrying capacity } \\
\text { models }\end{array}$} & \multicolumn{3}{|c|}{ Luwu Regency } & \multicolumn{3}{|c|}{ Palopo City } \\
\hline & Area (ha) & $\begin{array}{l}\text { Biocapacity } \\
\text { (ton) }\end{array}$ & $\begin{array}{l}\text { Carrying } \\
\text { capacity } \\
\text { (capita) }\end{array}$ & $\begin{array}{c}\text { Area } \\
\text { (ha) }\end{array}$ & $\begin{array}{c}\text { Biocapacity } \\
\text { (ton) }\end{array}$ & $\begin{array}{l}\text { Carrying } \\
\text { capacity } \\
\text { (kapita) }\end{array}$ \\
\hline Ecological Footprint & $59,781.79$ & $1,437,779.60$ & 21,432 & $1,771.41$ & $18,287.46$ & 635 \\
\hline Mass Balance nitrat & $38,374.69$ & $922,928.96$ & 13,595 & 979.82 & $10,115.34$ & 3,276 \\
\hline Buffer zone & $21,407.10$ & & & & & \\
\hline $\begin{array}{l}\text { Maximum tolerated } \\
\text { area }\end{array}$ & $48,083.93$ & $1,156,440.66$ & 17,034 & $1,418.43$ & $14,643.41$ & 4,743 \\
\hline Buffer zone & $11,697.86$ & & & & & \\
\hline
\end{tabular}




\section{Dynamic Management Model System}

The dynamic management models system approach can be used as a tool to analyze and make a policy in managing coastal areas for the development of the Eucheuma cottonii seaweed cultivation business based on the water carrying capacity in Luwu Regency and Palopo City. The results of the dynamic system analysis are a function of time (time domain) for seaweed farming activities, where the results obtained are not a prediction (forecasting) of a phenomenon, but only reflects off the trend of a phenomenon that might occur. The fundamental difference from the notion of trends and predictions (variability) is a trend (tendency) is a general description of the timing of a certain time (time domain), while predictions (variability) is a prediction of events that may be repeated based on certain frequencies (frequency domain).

The success of the Eucheuma cottonii seaweed has been influenced by the quality of the water, which is strongly influenced by how much anthropogenic waste enters the waters. Thus, controlling the level of pollution is a key factor in maintaining water quality, so that it will be maintained. Based on these considerations, the step management strategy for seaweed development uses the input of anthropogenic waste as a management scenario control. Some alternative scenarios for the management of development systems in the dynamic model of the input from waste in the current conditions, suppressing waste by $10 \%, 25 \%$, and $50 \%$. The results of the four management scenarios are shown in Figure 4 and Table 8.

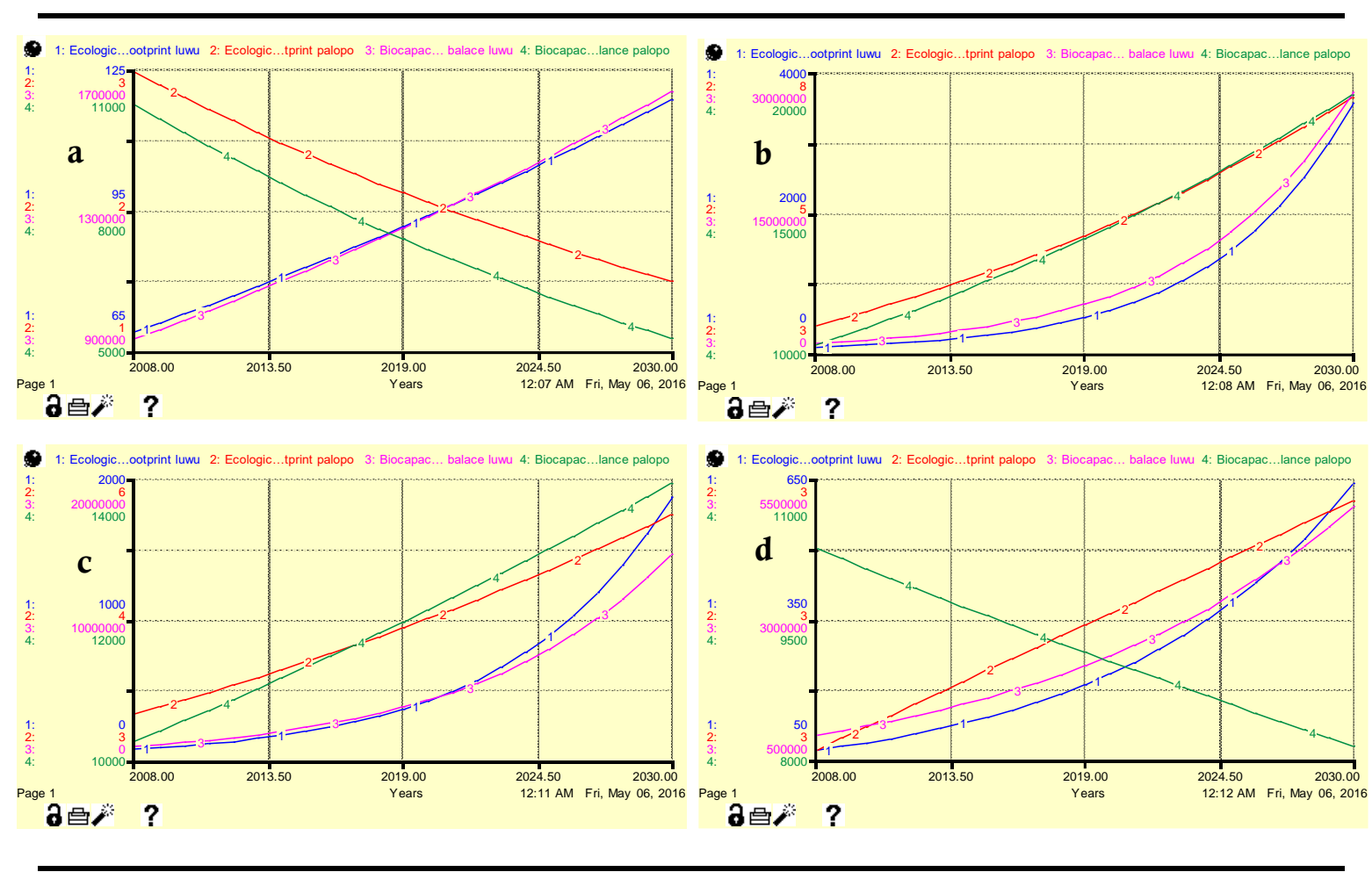

Figure 4. Results of management scenarios, a). current waste input, b). pressing waste $10 \%$, c). pressing waste $25 \%$ waste, c). pressing waste $50 \%$.

Based on the simulation results of four management scenarios for the development of seaweed cultivation in Luwu Regency, it shows that in 2nd scenario by reducing waste input by $10 \%$ from the current input of existing waste, and assuming that all of the available waters are 38,374.69 continuously (on the scale of 2008-2030), it will produce the highest water biocapacity, which is $8,257,274.94$ tons/year. Likewise with seaweed management in Palopo City with 2nd scenario, assuming that utilizing all available watershed areas of 979.82 
hectares will produce the highest water biocapacity of $14,306.92$ tons/year. If it is connected between the average nitrate concentration of $0.34 \mathrm{mg} / 1$ and management by pressing the waste input by $10 \%$, it will produce the highest water biocapacity. It can be interpreted that by pressing waste by $10 \%$ it will produce the optimum nitrate concentration for the growth of Eucheuma cottonii seaweed, which is $90 \%$ of the nitrate concentration in the waters $(90 \%$ of $0.34 \mathrm{mg} / \mathrm{l}$ ) which is equal to $0.30 \mathrm{mg} / 1$. In general, each type of seaweed is different from the different concentrations of nitrate for its growth. Nitrate can also be a limiting factor for seaweed. Based on Harrison and Hurd (2001) states that we will consume more nitrate than phosphate, and we will be vulnerable to the limitations of nitrate.

Table 8. The results of seaweed management scenarios

\begin{tabular}{lllllll}
\hline Scenario & Luwu regency & \multicolumn{3}{c}{ Palopo city } \\
\hline & $\begin{array}{l}\text { Biocapacity } \\
\text { (ton/year) }\end{array}$ & $\begin{array}{l}\text { EFP } \\
\text { (ton/capita) }\end{array}$ & $\begin{array}{l}\text { Carrying } \\
\text { capacity } \\
\text { (capita) }\end{array}$ & $\begin{array}{l}\text { Biocapacity } \\
\text { (ton/year) }\end{array}$ & $\begin{array}{l}\text { EFP } \\
\text { (ton/capita) }\end{array}$ & $\begin{array}{l}\text { Carrying } \\
\text { capacity } \\
\text { (capita) }\end{array}$ \\
\hline $\begin{array}{l}\text { Waste present } \\
\begin{array}{l}\text { Pressing waste } \\
10 \%\end{array}\end{array}$ & $\begin{array}{l}1,262,284.08 \\
\text { 8,257,274.94 }\end{array}$ & 92.25 & 13,668 & $7,506.88$ & 2.16 & 3,477 \\
$\begin{array}{l}\text { Pressing waste } \\
25 \%\end{array}$ & $5,121,751.01$ & 566.37 & 10,439 & $14,306.92$ & 4.74 & 3,069 \\
$\begin{array}{l}\text { Pressing waste } \\
50 \%\end{array}$ & $2,453,202.10$ & 260.85 & 10,439 & $9,164.39$ & 2.99 & 2,069 \\
\hline
\end{tabular}

\section{CONCLUSION}

Based on the analysis of the water carrying capacity of the combined two seasons illustrate representative of carrying capacity of water for one year in Luwu Regency and Palopo City, it can be referenced and scientific considerations for decision making in managing and developing a seaweed cultivation in both regions. By considering this potential, seaweed farming is expected to produce more optimal production. To find out the optimum biocapacity of water fluctuations, a dynamic model system was prepared using Stella Software. In models of dynamic systems management scenarios is done by considering the input of waste as a primary control, of the which four are input waste management scenario at this point, pressing waste $10 \%, 25 \%$ and $50 \%$. Based on the scenarios, the $10 \%$ waste that is the water of the waters, it will produce the highest water biocapacity compared to other scenarios. Thus, the steps that need to be controlled are the input of anthropogenic waste originating from land.

\section{REFERENCE}

Adrianto L. 2010. Fishery resources appropriation as sustainability indicator: An ecological footprint approach. Bogor: PKSPL IPB.

Albin S. 1997. Building a system dynamics model. Part 1: Conceptualization. Prepared for the MIT system dynamics in education project under the supervision of Dr. Jay W. Forrester. Massachusetts Institute of Technology. D-4597.

Alstyne KLV, Pelletreau KN. 2000. Effects of nutrient enrichment on growth and phlorotannin production in Fucus gardneri embryos. J Mar Ecol Prog Ser, 206: 33-43.

[AMWQ] ASEAN Marine Water Quality. 2008. Management guidelines and monitoring manual. Jakarta: The ASEAN Secretariat.

[APHA] American Public Health Association. 1998. Standard methods for the examination of water and wastewater (20 $0^{\text {th }}$ Edition ed.). Washington D.C. USA.

Bastianoni S, Niccolucci V, Neri E, Cranston G, Galli A, Wackernagel M. 2013. Sustainable development: Ecological Footprint in accounting. in Encyclopedia of environmental management. New York: Taylor and Francis, (2013):2467-2481. 
Boyd CE dan Lichtkoppler F, 1982. Water quality management in pond fish culture. (4 ${ }^{\text {th }}$ Edition ed.). International Center for Aquaculture, Agriculture Experiment Station, Auburn, USA.

[BPS] Badan Pusat Statistik. 2010. Kabupaten Luwu Dalam Angka Tahun 2010. Belopa: BPS Kab. Luwu

[BPS] Badan Pusat Statistik. 2014. Kabupaten Luwu Dalam Angka Tahun 2014. Belopa: BPS Kab. Luwu

[BPS] Badan Pusat Statistik Kota Palopo. 2014. Kota Palopo Dalam Angka Tahun 2013. Palopo: BPS Kota Palopo.

Ding L, Ma Y, Huang B, Chen S. 2013. Effects of seawater salinity and temperature on growth and pigment contents in Hypnea cervicornis J. Agardh (Gigartinales, Rhodophyta). (Lin H, Ed). Hindawi Publishing Corporation. J BioMed Research International, 2013:10.

[DKP] Dinas Kelautan dan Perikanan Kabupaten Luwu. 2011. Analisis lokasi unggulan untuk pengembangan budidaya rumput laut (Eucheuma cottonii) di perairan pesisir Kabupaten Luwu, Belopa: DKP Kab. Luwu

[DKP] Dinas Kelautan dan Perikanan Kabupaten Luwu. 2014. Kajian pembentukan Daerah Perlindungan Laut (DPL) Kabupaten Luwu. Belopa: DKP Kab. Luwu.

[DKP] Dinas Kelautan dan Perikanan Kabupaten Luwu. 2015. Laporan tahunan perikanan Kabupaten Luwu tahun 2010-2014. Belopa: DKP Kab. Luwu.

[DKP] Dinas Kelautan dan Perikanan Kota Palopo. 2015. Laporan tahunan DKP Kota Palopo tahun 2010-2014. Palopo: DKP Kota Palopo.

Fong P, Paul VJ. 2011. Coral reef algae. in Z. Dubinsky and N. Stambler, editors. Coral reefs: an ecosystem in transition. Springer, 241-272

Glenn EP, Doty MS. 1981. Photosynthesis and respiration of the tropical red seaweeds, Eucheuma Striatum (Tambalang and Elkhorn Varieties) and E. denticulatum. J Aquatic Botany, 10:353-364.

Harpole WS, Ngai JT, Cleland EE, Seabloom EW, Borer ET, Bracken MES, Elser JJ, Gruner DS, Hillebrand H, Shurin JB, Smith JE. 2011. Nutrient co-limitation of primary producer communities. J Ecology Letters, 14:852-62.

Harrison PJ, Hurd CL. 2001. Nutrient physiology of seaweeds : Application of concepts to aquaculture. J Cahiers de Biologie Marine, 42:71-82.

Hayashi L, Faria GSM, Nunes BG, Zitta CS, Scariot LA, Rover T, Felix MRL, Bouzon ZL, 2010. Effects of salinity on the growth rate, carrageenan yield, and cellular structure of Kappaphycus Alvarezii (Rhodophyta, Gigartinales) cultured in vitro. Journal of Applied Phycology, 23(3):439-447.

Hurd CL, Harrison PJ, Druehl LD. 1996. Effect of seawater velocity on inorganic nitrogen uptake by morphologically distinct forms of Macrocystis integrifolia from wavesheltered and exposed sites. J Mar Biol, 126:205-214

Hurd CL, Harrison PJ, Bischof K, Lobban CS. 2014. Seaweed ecology and physiology. (2 $2^{\text {th }}$ Edition ed.). Cambridge: Cambridge University Press.

Isee System. 2016. Technical document for the iThink and STELLA Software. Available at: http://www.iseesystems.com. Accessed 17 February 2016.

Kapraun DF. 1978. Field and culture studies on growth and reproduction of Callithamnion byssoides (Rhodophyta, Ceramiales) in North Carolina. J. Phycol, 14:21-24

Kawabe M, Kawabe M. 1997. Temporal and spatial characteristics of chemical oxygen demand in Tokyo Bay. Journal of Oceanography, (53):443-453.

[KLH] Kementerian Lingkungan Hidup R.I. 1988. Keputusan Menteri Negara Kependudukan dan Lingkungan Hidup Nomor 02 Tahun 1988 tentang Pedoman Penetapan Baku Mutu Lingkungan. Jakarta.

[KLH] Kementerian Lingkungan Hidup R.I. 2004. Keputusan Menteri Negara Kependudukan dan Lingkungan Hidup Nomor 51 Tahun 2004 tentang Baku Mutu Air Laut. Jakarta.

MacLeod M, Cooper JAG. 2005. Carrying capacity in coastal areas. Encyclopedia of Coastal Science. Springer: Schwartz M. (Ed.).

Mairth OP, Zodape ST, Tewari A, Rajyaguru MR. 1995. Culture of marine red alga Kappaphycus Striatum (Schmitz) Doty on the Saurashtra Region, West Coast of India. Indian J. Mar. Sci, 24:24-31.

Nybakken JW. 1992. Biologi laut suatu pendekatan ekologis. Jakarta: Gramedia.

[PERDA] Peraturan Daerah Kabupaten Luwu. 2011. Rencana Tata Ruang Wilayah Kabupaten Luwu 2011 2031.

[PHILMINAQ] Mitigating Impact from Aquaculture in the Philippines. Annex 2. 2006. Water Quality Criteria and Standards for Freshwater and Marine Aquaculture <URL:http://www.aquaculture.asia/files/PMNQ\%20 WQ\%20standard\%202.pdf. Accessed 20 December 2015.

Prahasta E. 2002. Konsep-konsep dasar sistem informasi geografis. Bandung: CV Informatika. 
Prema D. 2013. Site selection and water quality in mariculture. Central Marine Fisheries Research Institute. CMFRI Manuel Customized training Book. Kerala. India.

Randers J. 1980. Elements of the system dynamics method. Portland : Productivity Press. 344 pp.

Redmond S, Green L, Yarish C, Kim J, Neefus C. 2014. New England seaweed culture handbook-nursery systems. Connecticut Sea Grant CTSG-14-01. 92 pp.

Rees WE. 1992. Ecological Footprint and appropriated carrying capacity : what urban economics leaves out. J Environment and urbanization, 4:2.

Rees WE. 1996. Revisiting carrying capacity: area-based indicators of sustainability. J Population and Environment, (17):195-215.

Riani E. 2012. Perubahan iklim dan kehidupan biota akuatik (Dampak pada bioakumulasi bahan berbahaya dan beracun \& reproduksi). Institut Pertanian Bogor: IPB Press.

Samawi MH. 2007. Desain sistem pengendalian pencemaran pantai kota (studi kasus perairan pantai Kota Makassar) [tesis]. Bogor: Institut Pertanian Bogor.

Sastrawijaya AT. 2000. Pencemaran Lingkungan. Jakarta: Rineka Cipta.

Setiyanto D, Efendi I, Antara KJ. 2008. Pertumbuhan Kappaphycus alvarezii var Maumare, var Sacol dan Eucheuma cottonii di Perairan Musi Buleleng. Jurnal Ilmu Kelautan, 13(3):171-176.

Shanmugam P, Neelamani S, Hwan Ahn Y, Philip L, Hoon Hong G. 2006. Assessment of the levels of coastal marine pollution of Chennai city, Southern India. J Water Resour Manage, DOI 10.1007/s11269-0069075-6.

[UNEP] United Nations Environment Programme. 1996. Carrying capacity assessment for tourism development. Coastal Area Management Programme (CAMP). FUKA-MATROUH. Egypt.

Wackernagel M. 1994. Ecological Footprint and appropriated carrying capacity: a tool for planning toward sustainability [dissertation]. Vancouver, Canada: School of Community and Regional Planning. The University of British Columbia.

Wackernagel M, Rees WE. 1996. Sharring nature interest. London: Earth Scan Publication. 186p.

Widigdo B, Pariwono J. 2003. Daya dukung perairan di pantai utara Jawa Barat untuk budidaya udang (Studi kasus di Kabupaten Subang, Teluk Jakarta dan Serang). Jurnal Ilmu-Ilmu Perairan dan Perikanan Indonesia, 1:10-17.

Yong WTL, Ting SH, Yong YS, Thien VY, Wong SH, Chin WL, Rodrigues KF, Anton A. 2013. Optimization of culture conditions for the direct regeneration of Kappaphycus alvarezii (Rhodophyta, Solieriaceae). J Appl Phycol. DOI 10.1007.

[YSI Inc] Yellow Springs Instrument Incorporated. 2006. The basics of chlorophyll measurement. In YSI Environmental. Tech Note. Retrieved from http://www.ysi.com/media/pdfs/T606-The-Basics-ofChlorophyll-Measurement.pdf

Zang H, Li L, Zou Z. 2015. The research of seawater chemical oxygen demand measurement technology with ozone oxidation method. Shao F, Shu W and Tian T (Eds). Proceedings of the 2015 International Conference on Electric, Electronic and Control Engineering. London : Taylor \& Francis Group. 787. 